\title{
Sosialisasi Manajemen Penyelenggaraan Paud
}

\author{
Mahkamah Brantasari \\ Universitas Widya Gama Mahakam Samarinda, Indonesia \\ mahkamah@uwgm.ac.id
}

\begin{abstract}
Paud is an organization engaged in early childhood education that must be very well managed and maximally organized because paud is a learning platform that focuses on children who have a golden age whose time span is only short and must be really serious in implementing the learning system so that it is in line with the goals and directions of early childhood education. Planning is the initial foundation of an activity can and will be carried out, in planning made a goal, which is summarized in the vision and mission of the organization, the next activity is organizing, after planning then what must be considered is how activities can be carried out properly according to objectives, activities that must be carried out is the distribution of tasks to experts in accordance with predetermined fields. Furthermore, the implementation of the plans that have been made, implementation is a process that is carried out continuously repeatedly so that there is a need for a control or supervision to ensure that the implementation of activities runs well in accordance with the provisions that have been planned.
\end{abstract}

Keywords: PAUD administration, PAUD management

\begin{abstract}
Abstrak
Paud merupakan organisasi yang bergerak dalam dunia pendidikan anak usia dini harus dikelola dengan sangat baik dan terorganisir secara maksimal karena paud sebagai wadah pembelajaran yang fokus pada anak yang memiliki masa golden age yang rentang waktunya hanya sebentar dan harus benar-benar serius dalam melakukan pelaksanaan sistem pembelajaran supaya sesuai dengan tujuan dan arah dari pendidikan anak usia dini. Perencanaan merupakan pondasi awal suatu kegiatan dapat dan akan dilaksanakan, pada perencanaan di buat suatu tujuan, yang dirangkum dalam visi misi organisasi, kegiatan selanjutnya adalah pengorganisasian, setelah di rencanakan kemudian yang harus dipikirkan adalah bagaimana kegiatan dapat terlaksana dengan baik sesuai tujuan, kegiatan yang harus dilakukan adalah pembagian tugas kepada orang yang ahli sesuai dengan bidang yang telah ditentukan. Selanjutnya pelaksanaan dari pada rencana yang telah dibuat, pelaksanaan merupakan proses yang dilakukan secara terus menerus berulangkali sehingga perlu adanya suatu control atau pengawasan untuk memastikan pelaksanaan kegiatan berjalan dengan baik sesuai dengan ketetapan yang telah di rencanakan.
\end{abstract}

Kata kunci; Penyelenggaraan PAUD, Manajemen PAUD

\section{PENDAHULUAN}

Keberadaan lembaga-lembaga PAUD diwilayah kota samarinda dan sekitarnya perlu di imbangi dengan kemampuan dan juga pemahaman mengenai manajemen penyelenggaraan PAUD, agar dalam pelaksanaannya sesuai dengan harapan dan tujuan serta cita-cita awal didirikannya Lembaga PAUD yang dalam manajemen penyelenggaraan PAUD ada beberapa hal yang mesti di perhatikan yaitu, mulai dengan pendiriannya, pengelolaan secara teknis dan juga pembelajaran hingga evaluasi dan pembinaannya.

Paud merupakan organisasi yang bergerak dalam dunia pendidikan anak usia dini harus dikelola dengan sangat baik dan terorganisir secara maksimal karena paud sebagai wadah pembelajaran yang fokus pada anak yang memiliki masa golden age yang rentang waktunya hanya sebentar dan harus benar-benar serius dalam melakukan pelaksanaan sistem pembelajaran supaya sesuai dengan tujuan dan arah dari Pendidikan anak usia dini.

Senada dengan (Suharti, 2018) Konsep "golden ages" diperkuat dengan kenyataan yang para ahli temukan. Pertumbuhan jaringan otak pada anak usia 3 tahun mencapai 80 persen, dan apabila rajin melakukan stimulus maka usia 6 tahun akan mencapai 85 persen, dan mencapai puncak 100 persen ketika anak berusia 8 hingga usia 18 tahun. Untuk Pertumbuhan fungsi- 
fungsi sel saraf pada anak membutuhkan beragam kondisi yang mendukung pendidikan, misalnya lingkungan keluarga, sekolah dan masyarakat di sekitarnya. Neurologi menyatakan bahwa pada saat lahir otak bayi mengandung 100-200 miliar neuron atau sel saraf yang siap melakukan sambungan antar sel. Ahli pendidikan mengatakan bahwa pertumbuhan periode keemasan hanya berlangsung satu kali dalam kehidupan manusia.

Dengan keadaan yang demikian maka di perlukan adanya sosialisasi mengenai manajemen penyelenggaraan Paud yang bertujuan dalam pengelolaan Lembaga kepaudan dilaksanakan sesuai dengan mekanisme organisasi yang tentunya dapat dijalankan dengan baik dan mudah, sehingga pihak-pihak yang terlibat dalam Lembaga tersebut merasa nyaman dan Bahagia dalam menjalankan organisai Lembaga paud. Manajemen penyelenggaraan paud adalah suatu himpunan yang terdiri dari beberapa kegiatan untuk mencapai satu atau beberapa tujuan yang dimulai dengan kegiatan planning, organizing, actuating dan controlling. Dalam buku (Syafaruddin, 2015) Menurut Daft dan Marcic (2009:8) management is the attainment of organizational goals in an effective and efficient manner through planning, organizing, leading, and controlling organizational resources. Definisi ini menjelaskan bahwa kegiatan perencanaan, pengorganisasian, kepemimpinan dan pengawasan sumberdaya organisasi manajemen merupakan pencapaian sasaran organisasi secara efektif dan efisien.

Kegiatan perencanaan adalah kegiatan awal yang harus di dahulukan karena perencanaan merupakan pondasi awal mula arah langkah suatu kegiatan dapat dan akan dilaksanakan, pada perencanaan di buat suatu tujuan, yang dirangkum dalam visi misi organisasi, kegiatan selanjutnya adalah pengorganisasian, setelah di rencanakan kemudian harus dipikirkan adalah bagaimana kegiatan dapat terlaksana dengan baik sesuai tujuan, maka kegiatan yang harus dilakukan adalah pembagian tugas kepada orang yang ahli sesuai dengan bidang yang telah ditentukan. Selanjutnya adalah pelaksanaan dari pada rencana yang telah dibuat, pelaksanaan merupakan proses yang dilakukan secara terus menerus berulangkali sehingga perlu adanya suatu control atau pengawasan untuk memastikan pelaksanaan kegiatan berjalan dengan baik sesuai dengan ketetapan yang telah di rencanakan.

Dengan mengacu pada visi misi yang telah dibuat memudahkan pengelola lembaga dalam pengadaan prasarana dan sarana. Kebutuhan materi lembaga menjadi lebih mudah di identifikasi, sesuai kebutuhan yang pasti akan berbeda dengan kebutuhan lembaga lain.

Pengadaan prasarana dapat berupa pengadaan lahan, untuk bangunan sebagai tempat beraktivitasnya lembaga. Contohnya lahan untuk membangun gedung untuk tempat belajar, perpustakaan, kantor, taman dan sebagainya. Menurut M. Daryanto dalam (Prastyawan, 2016) Prasarana pendidikan adalah segala macam kebutuhan yang diperlukan berupa peralatan, kelengkapan, dan materi yang digunakan guru dan murid bertujuan memudahkan penyelenggaraan pendidikan.

Sedangkan sarana dapat berupa kebutuhan akan peralatan dan perlengkapan kegiatan, misalnya meja, kursi, lemari, rak, dan kebutuhan lainnya untuk memperlancar kegiatan belajar mengajar. Menurut Suharsimi Arikunto masih dalam (Prastyawan, 2016) Sarana pendidikan adalah semua peralatan yang digunakan guru bertujuan untuk memudahkan penyampaian materi pelajaran. kebutuhan murid, mengenai keperluan pendidikan adalah semua peralatan yang digunakan murid untuk memudahkan mempelajari mata pelajaran yang di berikan.

Mengelola orang-orang yang terlibat dalam Lembaga, yang terdiri dari tenaga pendidik yakni guru, yaitu orang yang di harapkan memiliki keahlian atau kualifikasi dalam keguruan khususnya pendidikan anak usia dini. (Murni, 2017) Pendidik adalah tenaga kependidikan yang memiliki keahlian sebagai pendidik, seperti guru, dosen, penyuluh, dan sebutan lain yang di tujukan kepada pengajar sesuai dengan keahliannya, dimana mereka terlibat dalam penyelenggaraan pendidikan (Undang-undang Nomor 20 Tahun 2003 Tentang Sistem 
Pendidikan Nasional). Pengertian guru di peruntukan kepada pengajar pada tingkat dasar hingga menengah. Dan sebutan dosen untuk pendidik pada tingkat perguruan tinggi. Adapaun pendidik itu sendiri merupakan perantara aktif dalam penyampaian ilmu pengetahuan yang ada pada sekolah hingga perguruan tinggi serta menyampaikan nilai-nilai dan norma-norma susila yang tinggi dan luhur untuk bekal bermasyarakat

Dan tenaga kependidikan sendiri merupakan orang-orang yang terlibat dalam kelancaran proses kegiatan belajar mengajar, menurut (Idris, 2014: 53) dalam artikel (Suarga, 2019) Undang- Undang Tahun 2003 No. 20 pasal 1 ayat 5 dan 6 tentang sistem pendidikan Nasional yang dimaksud dengan tenaga kependidikan adalah anggota masyarakat yang mengabdikan diri dan diangkat untuk menunjang penyelanggaran Pendidikan. Tenaga kependidikan memiliki tugas untuk memenuhi kebutuhan dan kelengkapan dari tenaga pendidik dan juga peserta didik. Aktivitas tenaga kependidikan itu sendiri berkaitan dengan pelaksanaan adiminitrasi, pengelola keuangan dan hal-hal yang bersifat layanan.

\section{METODE PELAKSANAAN}

Kegiatan ini dilaksanakan dalam bentuk seminar dengan tema "Sosialisasi Manajemen Penyelenggaraan Paud" dalam program pengabdian masyarakat, hal ini diharapkan dapat memberikan pengetahuan kepada pengelola, tenaga pendidik dan kependidikan di Lembaga PAUD yang ada di wilayah kota Samarinda dan sekitarnya.

Seminar dilaksanakan dalam dua tempat dengan hari dan waktu yang berbeda, seminar pertama dilaksanakan bertempat pada Paud Tunas harapan. Acara dilaksanakan tanggal 15 Januari 2020 mulai pukul 14.00 pagi hingga 15.45 siang. Dan seminar kedua dilaksanakan pada aula gedung kampus UWGM Samarinda. Pada pukul 10.00 pagi hingga 11.45 siang, tanggal 18 Januari 2020.

Dengan target kegiatan adalah pengelola, tenaga pendidik dan kependidikan yang ada di kota Samarinda dan sekitarnya. Oleh karena itu, ditetapkan kerangka pemecahan masalah secara operasional sebagai berikut:

a) Menetapkan jumlah peserta Seminar Sosialisasi Manajemen Penyelenggaraan PAUD di Wilayah Kota samarinda

b) Semua peserta dikumpulkan di suatu tempat/ruangan yang memadai untuk penyelenggaraan seminar.

c) Memberikan materi seminar yang meliputi :

1. Pengertian manajemen penyelenggaraan PAUD

2. Pemahaman dalam :

1) Pengertian manajemen secara umum

2) Mengidentifikasi manajemen penyelenggaran paud
a. Prinsip-prinsip penyelenggaraan program
b. Komponen Program penyelenggaraan PAUD
c. Teknis pembentukan dan pembelajaran di PAUD
d. Pengertian Evaluasi dan pembinaan 


\section{HASIL DAN PEMBAHASAN}

\section{a. Seminar 1 bertempat pada Paud Tunas Harapan}

Kegiatan yang pertama dilaksanakan di kelurahan Makroman tepatnya di PAUD Tunas Harapan yang di hadiri oleh guru-guru anggota HIMPAUDI kecamatan Sambutan. Acara ini sangat di dukung oleh pengurus HIMPAUDI kecamatan, yang berharap kegiatan ini dapat dilaksanakan secara rutin dengan tema yang bervariasi, karena sangat membantu pengurus lembaga, pendidik PAUD dan pihak-pihak yang terkait dalam mengelola lembaga menuju arah yang lebih baik. Acara di mulai dengan pembukaan, ramah tamah pemilik PAUD Tunas Harapan dan lanjut dengan kegiatan seminar hingga selesai.

Seminar diawali dengan pembukaan yang dilaksanakan oleh petugas dari guru PAUD Tunas Harapan, ibu Muslimah, setelah itu di serahkan kepada moderator yaitu ibu Rasmen selaku kepala PAUD Tunas Harapan, salam dan pengenalan diri pemateri, yang dilanjutkan dengan pemaparan mengenai Manajemen Penyelenggaraan PAUD. Peserta nampak antusias dalam mendengarkan pemamparan yang disampaikan hingga selesai. Materi yang disampaikan berkaitan dengan pengertian manajemen secara umum, prinsipprinsip penyelenggaraan program Pendidikan, komponen program penyelenggaraan PAUD, Teknis Pembentukan dan pembelajaran hingga evaluasi dan pembinaan. Setelah materi di paparkan dilanjutkan dengan sesi tanya jawab.

Pada sesi tanya jawab peserta bertanya, ada seorang guru PAUD dari PAUD Tunas Harapan yang menanyakan mengenai hal-hal yang berhubungan dengan prinsip-prinsip penyelenggaraan paud, alasannya menanyakan hal ini adalah untuk lebih percaya diri dalam melaksanakan pembelajaran di lembaganya, dan agar mengingat kembali pelajaran yang pernah di dapat di bangku kuliah. Pemateri memberikan jawaban dengan menyesuaikan materi yang ada di perkuliahan mengenai prinsip penyelenggaraan PAUD, dengan mengingatkan kembali mengenai prinsip dasarnya yang pertama adalah:

1 Tujuan PAUD itu sendiri apa saja, yang jelas harus berorientasi pada kebutuhan anak didik, lingkungan yang aman dan nyaman bagi anak, anak sukanya bermain maka belajar dilaksanakan dengan bermain, kalau bisa pembelajaran yang diberikan mencakup beberapa aspek sesuai dengan tumbuh kembang anak, sehingga anak cakap dalam mengatasi kehidupannya, dilakukan secara berulang-ulang dan dianjurkan menggunakan media dalam pembelajarannya.

2 Perihal tersebut dilaksanakan dengan tidak bertentangan dengan prinsip-prinsip Pendidikan umumnya yang harus berlandaskan pada landasan filosofis, landasan yuridis, landasan psikologis dan landasan keilmuannya.

Pertanyaan selanjutnya adalah mengenai pengelolaan keuangan yang ada di lembaga PAUD, yang mana di lembaga ada memiliki bendahara tetapi keuangan terkadang masih di pegang oleh kepala sekolah. Bukan karena kepala sekolah tidak percaya kepada bendahara tetapi bendahara lebih suka apabila keuangan di pegang oleh kepala sekolah. Dimana-mana masalah keuangan adalah masalah sensitif, sulit namun sebenarnya mudah, maksudnya adalah benar sudah ada bendahara yang mengelola tetapi seringkali muncul ketidak percayaan diri dari seorang bendahara untuk mengendalikan keuangan, entah itu perasaan tidak nyaman dan sebagainya, masalah ketidak percayaan diri dalam mengelola keuangan.

Masalah ini tentu harus ada motivasi yang harus di berikan kepada bendahara, sehingga muncul kepercayaan diri yang sesungguhnya, yang harus di dukung oleh pihakpihak yang terkait, tidak boleh ada intimidasi. Karena alangkah baiknya apabila seorang yang sudah di percaya sebagai bendahara berlakulah selayaknya bendahara berdasarkan 
tugas dan fungsi dari bendahara itu sendiri sesuai dengan prosedur yang sudah di sepakati bersama,

Pihak-pihak lainnya (dalam hal ini pihak yang terkait dengan kelembagaan) juga apabila ada kepentingan dengan bendahara, terkait dengan pendapatan dan pengeluaran baiknya di bicarakan mengikuti alur yang ada, sehingga bendahara tidak merasa di intimidasi karena suatu hal, sehingga muncul rasa nyaman dalam menjalankan tugas masing-masing. Hal-hal yang berhubungan dengan pendapatan dan pengeluaran biasanya sudah di rapatkan pada rapat tahunan, bulanan dan seterusnya, sehingga terlihat jelas tentang anggaran rutin dan anggaran tahunan berdasarkan alokasi yang telah di tetapkan bersama. Masukan bagi lembaga dan pengurus adalah harus rajin mengadakan rapat sesuai dengan kebutuhan dan ketetapan dan libatkan semua pihak berdasarkan agenda rapat tersebut. Sehingga semua menjadi transparan tanpa ada salah paham.

Kedua pertanyaan tersebut sangat menarik untuk diperhatikan karena pada dasarnya pelaku penyelenggara PAUD secara teoritis sudah tahu dan belajar namun memerlukan penguatan pada rasa percaya diri dalam pelaksanaannya sehingga perlu sering dilakukan kegiatan-kegiatan langsung seperti studi banding, kunjungan-kunjungan ke Lembagalembaga PAUD lainnya sebagai bahan perbandingan dan belajar secara langsung sehingga mudah dalam prakteknya. Demikian tanya jawab ini yang juga diselingi dengan canda tawa serta contoh-contoh yang terjadi di lapangan, yang semuanya memerlukan komunikasi yang baik antara pihak yang ada di Lembaga PAUD yang bersangkutan. Setelah sesi tanya jawab selesai maka kegiatan selanjutnya adalah penutupan untuk menyatakan kegiatan selesai dengan baik.

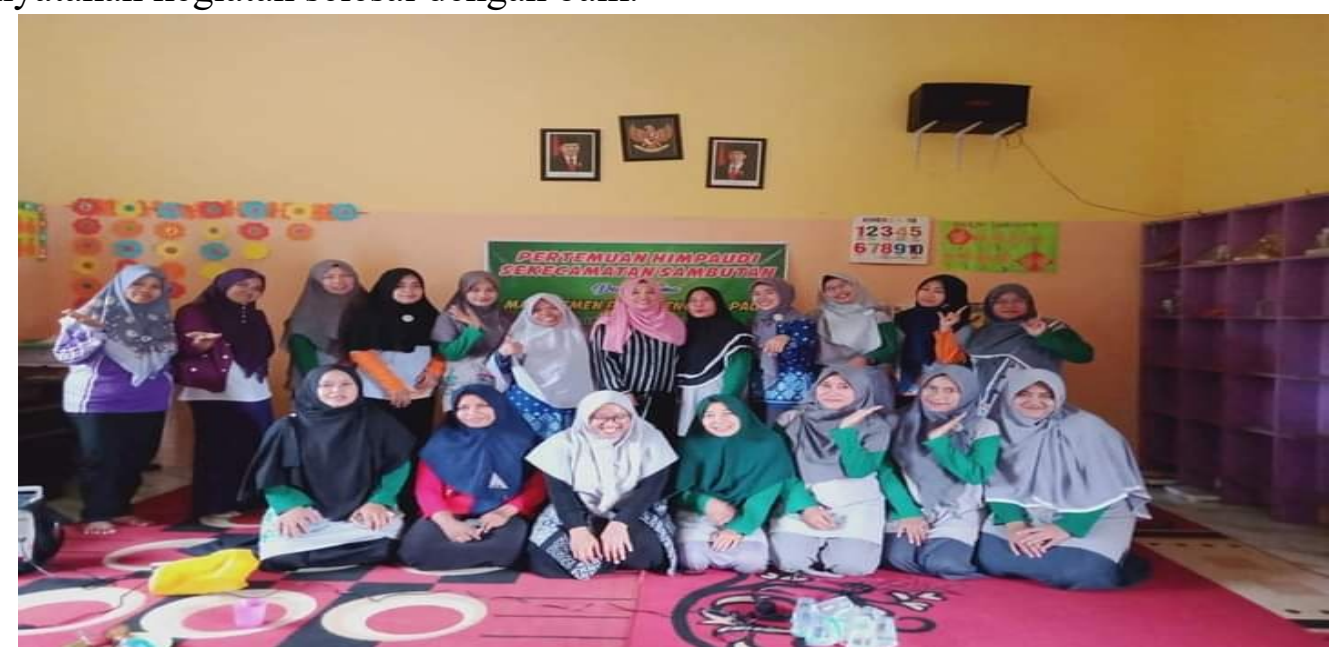

Gambar1. Suasana sosialisasi di PAUD Tunas Harapan Makroman Samarinda Sumber: koleksi pribadi

\section{b. Seminar 2 lokasi kampus UWGM Samarinda}

Seminar kedua di laksanakan di kampus UWGM Samarinda, yang di hadiri mahasiswa, alumni dan juga para guru PAUD di seputar wilayah kota Samarinda. Kegiatan di buka secara seremonial oleh pembawa acara dari mahasiswa PG PAUD, setelah pembukaan selesai maka di lanjutkan dengan penyerahan acara kepada moderator, sebagai moderator adalah saudari Suheni, S.Pd selaku alumni dari FKIP UWGM Samarinda. Moderator membacakan curiculum vitae pemateri. Setelah curiculum vitae di bacakan pemateri melakukan presentasi yang sudah disiapkan.

Presentasi dilakukan kurang lebih satu jam dengan memberikan menjelasan yang berhubungan dengan Manajemen Penyelenggaraan PAUD, pengertian manajemen secara 
umum beserta prinsip yang ada dalam manajemen, Komponen Program penyelenggaraan PAUD, Teknis pembentukan dan pembelajaran di PAUD serta Evaluasi dan pembinaan di lembaga PAUD. Setelah presentasi selesai dilanjutkan dengan tanya jawab, peserta memberikan pertanyaan, pertanyaan yang di lontarkan oleh salah satu guru PAUD berhubungan dengan persoalan peserta didik, yang berhubungan dengan layanan yang di berikan pihak sekolah itu harusnya bagaimana, pemateri menjelaskan mengenai peserta didik yang merupakan asset dari suatu lembaga PAUD, sehingga semestinya layanan yang di berikan sesuai dengan kebutuhan peserta didik tersebut. Tentunya perlu dilakukan survey atau pengamatan mengenai apa saja hal-hal yang merupakan kebutuhan peserta didik, terutama terkait dengan kenyamanan, keamanan dan keperluan lainnya terkait dengan Pendidikan.

Ada beberapa hal yang bisa segera dilakukan dalam layanan yang di berikan, misalnya saja, pertama: layanan dalam pelaksanaan pendaftaran (perekrutan) sebagai peserta didik baru. Dimulai dengan pendaftaran yang dibuat ringkas dan tidak berbelit, selain pendaftaran dilakukan secara manual, juga dapat di lakukan secara online, apalagi dengan keadaan sekarang yang semuanya menggunakan teknologi maka manfaatkanlah kemajuan tersebut dengan membuat webside yang menyediakan informasi yang berhubungan dengan profil lembaga PAUD tersebut. Dan konsumen bisa mendaftar secara online, pembayaran dilakukan online, kegiatan administrasi seperti formulir dan berkas-berkas sebagai syarat yang harus di penuhi oleh konsumen dapat dilakukan secara online. Kegiatan secara online meringkas waktu karena berkas secara otomatis dapat tersimpan langsung ke database lembaga PAUD.

Kedua, lakukan pertemuan dengan orangtua peserta didik. Sebelum kegiatan belajar mengajar di mulai lakukanlah rapat untuk pertemuan antara orang tua peserta didik dengan lembaga terkait. Agar apa yang menjadi keinginan baik dari konsumen atau stakeholder, dan juga lembaga dapat tersampaikan dengan baik. Ketiga: Layanan lainnya yang dapat dilakukan adalah dengan adanya layanan kesehatan sekolah untuk mengantisipasi terjadi kecelakaan atau sakit ringan yang bisa dialami oleh peserta didik. Keempat: layanan laboratorium juga dapat dilakukan untuk menopang proses pembelajaran peserta didik. Sehingga bakat dan kesukaan peserta didik dapat tersalurkan dengan baik.

Kemudian dalam kegiatan sehari-hari dalam pelaksanaan pembelajaran sekolah dengan memberikan perhatian-perhatian yang dapat di mulai dengan penyambutan peserta didik ketika baru datang dengan memberikan senyum, salam dan sapa yang di kenal dengan $3 \mathrm{~S}$. Hal-hal yang mungkin bisa dianggap kecil ini diharapkan berdampak besar bagi peserta didik, misalnya anak yang dari rumah, datang kesekolah dengan suasana hati anak yang tidak senang karena kesiangan, bangun dipaksa, mandi dipaksa, hingga membuat hati anak murung, maka dengan mendapatkan 3S dari guru, anak diharapkan dapat berubah suasana hatinya, menjadi senang dan merasa nyaman untuk mengikuti kegiatan kelas selanjutnya hingga pulang kembali ke rumah. Dilanjut hingga menjelang anak pulang sekolah dengan memberikan kerapian kebersihan anak hingga anak sampai ketangan kedua orang tuanya. Layanan-layanan tersebut merupakan contoh yang dapat dilakukan oleh pihak lembaga dalam meningkatkan pelayanan pada Lembaga PAUD masing-masing. Kegiatan berakhir hingga pukul 11.44 Wita, di tutup dengan membaca alhamdulillah dan pembagian sertifikat kepada peserta seminar. 


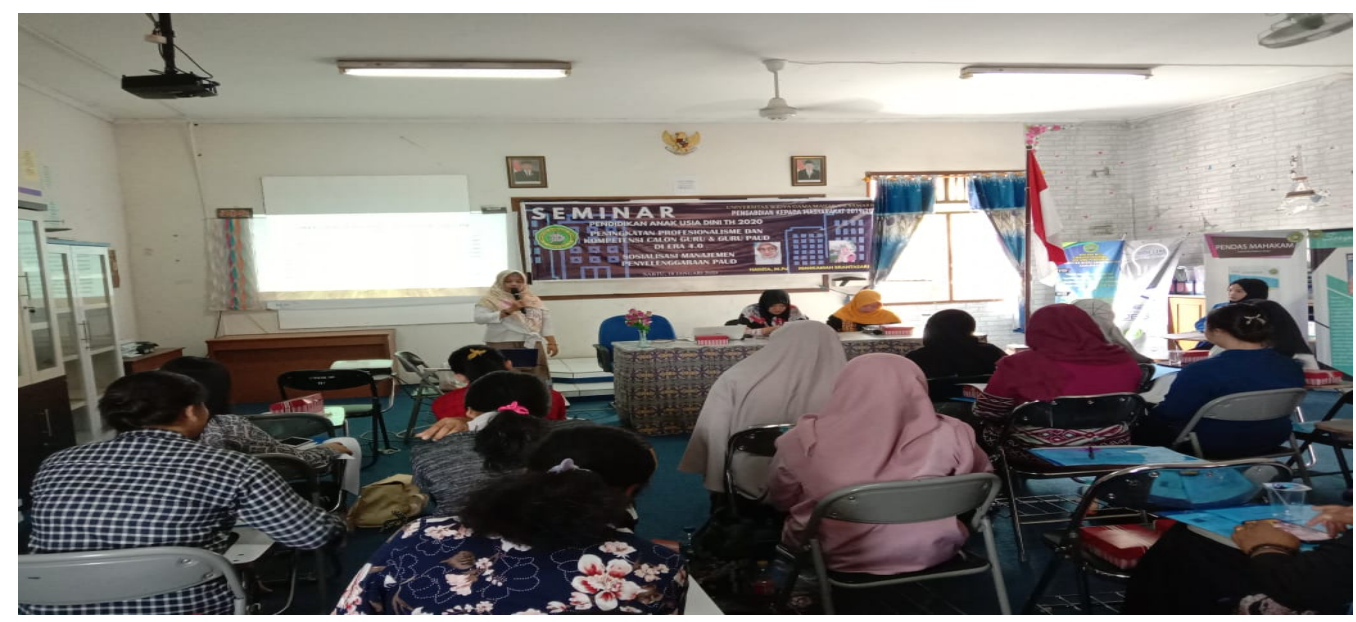

Gambar 2. Suasana sosialisasi di kampus Widya Gama Mahakam Samarinda Sumber: koleksi pribadi

\section{KESIMPULAN}

1. Seminar Sosialisasi Manajemen Penyelenggaraan Paud memotivasi para pemilik lembaga dan guru PAUD untuk menambah wawasan dalam pembelajaran manajemen.

2. Kesadaran mengenai pentingnya berperilaku professional dan pentingnya layanan terhadap peserta didik.

\section{Ucapan Terima Kasih}

Penulis mengucapkan terima kasih kepada Universitas Widya Mahakam Samarinda yang telah mendanai penelitian ini hingga selesai.

\section{DAFTAR PUSTAKA}

Murni. (2017). Manajemen Tenaga Pendidik an Kependidikan Paud. Intelektualita, 05, 19 pages. Retrieved from http://digilib.unimed.ac.id/1614/

Prastyawan. (2016). Manajemen Sarana Dan Prasarana Pendidikan Prastyawan 1. Al-Hikmah, $6(1), 35$.

SUARGA. (2019). Tugas Dan Fungsi Manajemen Pendidik Dan Tenaga Kependidikan. Idaarah, 3, 11. https://doi.org/10.1097/01.ede.0000417167.61785.27

Suharti, S. (2018). Manajemen Pendidikan Anak Usia Dini (PAUD) dalam Rangka Meningkatkan Mutu Pembelajaran (Studi pada PAUD Negeri Pembina Curup dan PAUD Pertiwi Kabupaten Rejang Lebong). Tadbir : Jurnal Studi Manajemen Pendidikan, 2(1), 51. https://doi.org/10.29240/jsmp.v2i1.397

Syafaruddin. (2015). Manajemen Organisasi Pendidikan: Perspektif Sains dan Islam. Medan: Perdana Publising.

\section{Profil Penulis:}

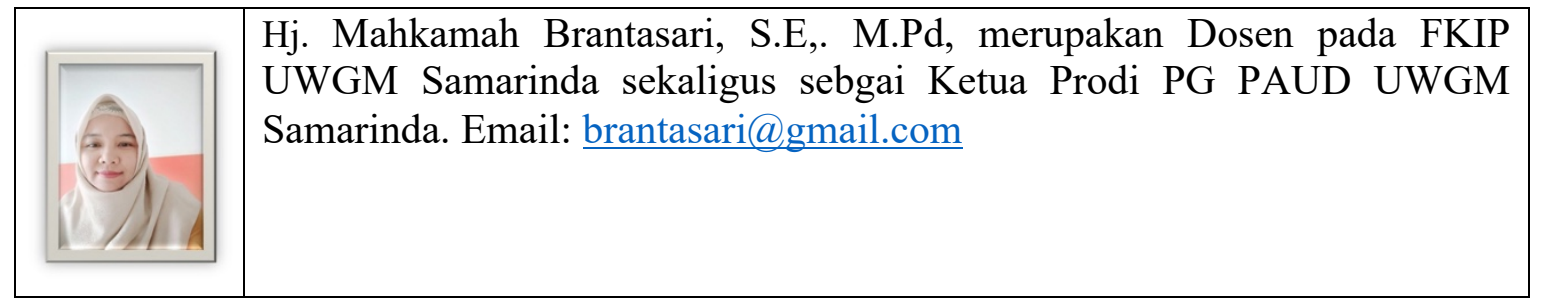

